\title{
Stress levels and quality of sleep in subjects with temporomandibular joint dysfunction
}

\section{Níveis de estresse e distúrbios do sono em indivíduos com disfunção temporomandibular}

\begin{abstract}
Purpose: The aim of this study was to test the association between quality of sleep and stress in individuals with temporomandibular disorder (TMD).

Methods: The study sample consisted of 354 adult subjects (males and females) from the municipality of Piacatu, São Paulo state, in the Southeast region of Brazil. Data were collected using the Fonseca's Questionnaire to record the level of TMD, the Pittsburgh Sleep Quality Index (PSQI) to assess quality of sleep and the Social Readjustment Rating Scale (SRRS) to record stress level. The data were analyzed by the software Epi Info 2000 version 3.2 using a chi-square test at the 0.05 level of significance.

Results: One hundred and eighty (50.8\%) subjects had some level of TMD. The statistical analysis showed a significant relationship between the three stress scores and the presence or absence of sleep disorders, considering an overall PSQI score $>5$ as an indicator of a subject with sleep problems $(P<0.01)$.

Conclusion: Both quality of sleep and stress levels were associated with TMD in this sample.

Key words: Temporomandibular joint; temporomandibular joint dysfunction syndrome; sleep disorders; stress
\end{abstract}

\section{Resumo}

Objetivo: O objetivo deste trabalho foi comparar níveis de estresse e qualidade do sono em indivíduos com DTM.

Metodologia: $O$ universo desta pesquisa constituiu-se por 354 indivíduos de ambos os sexos do município de Piacatu, SP, Brasil. Os dados foram coletados através do uso de: Questionário de Fonseca para verificar o grau de DTM, Índice da Qualidade do Sono de Pittsburgh (PSQI) para a qualidade do sono e a Escala de Reajustamento Social (SRRS) para o grau de estresse. Os dados foram tabulados por meio do programa Epi Info 2000, versão 3.2, e analisados estatisticamente por meio do Teste Qui-Quadrado, ao nível de significância de 5\%.

Resultados: Do total, 180 (50,8\%) apresentavam algum grau de disfunção temporomandibular, sendo que destes, $96(53,3 \%)$ tinham distúrbios do sono e 107 (59,4\%) graus mais elevados de estresse. $O$ teste estatístico mostrou relação entre os fatores analisados $(P<0,01)$.

Conclusão: Há associação estatisticamente significativa entre qualidade do sono e estresse em indivíduos com DTM.

Palavras-chave: Articulação temporomandibular; síndrome da disfunção da articulação temporomandibular; transtornos do sono; estresse

\section{Ronald Jefferson Martins a Cléa Adas Saliba Garbina Alício Rosalino Garcia a Artênio José Ísper Garbin a Natália Miguela}

\begin{abstract}
- Graduate Program in Social and Preventive Dentistry, Faculty of Dentistry of Araçatuba, São Paulo State University (UNESP), Araçatuba, SP, Brazil
\end{abstract}

Correspondence:
Ronald Jefferson Martins
NEPESCO - Center for Research in Public Health
Faculty of Dentistry of Araçatuba
São Paulo State University
Department of Children and Social Dentistry
R. José Bonifácio, 1193 - Vila Mendonça
Araçatuba, SP - Brasil
$16015-050$
E-mail: rojema@terra.com.br/cgarbin@foa.unesp.br 


\section{Introduction}

Temporomandibular joint dysfunction (TMD) consists of a series of clinical signs and symptoms involving the temporomandibular joint (TMJ) and/or masticatory muscles, with pain being the most frequent symptom. Several etiological factors including sleep disorders as well as physical, emotional and occlusal stress may decrease the adaptive capacity of the stomatognathic system and lead to the occurrence of the disorder (1).

Sleep disorders may reflect a state of wakefulness during the night, resulting in a feeling of restless sleep, psychological stress and chronic fatigue (2). Sleep is influenced by a large number of stressors, but the mechanisms associated with these stressors remain unclear. There is some evidence that relates these changes to the increased secretion of corticosteroids and norepinephrine. Some groups are more susceptible than are others to specific types of stress. The accumulation of functions associated with holding multiple roles in society is a major stressor for women, and the insecurity of an increasingly competitive labor market along with the financial crisis are important concerns for men (3).

Social events are considered as potential sources of stress, because they involve the need for active adaptation, which consequently involves changes in physiological processes to facilitate the development and adaptation of the expressed behaviors (4). Holmes and Rahe (5) studied a series of events known as units of life events. Through empirical findings, the authors demonstrated that there is a general consensus on the degree to which certain life events involve change and require readjustment by the individual. A life event becomes a stressor for the individual from the moment that it causes changes or requires the individual to reorganize his or her normal routine. The authors developed the Social Readjustment Scale (SRRS) to measure the risk or susceptibility of an individual to suffer disturbances in their health.

Given that different factors are associated with TMD and that stress is related to certain types of sleep disorders, the aim of this work was to analyze the association between stress and sleep disorders in patients with TMD.

\section{Methods}

The research protocol was approved by the Ethics Committee in Human Research, Faculty of Dentistry of Araçatuba, State University of São Paulo (UNESP) (process FOA 200501719). The sample consisted of 354 heads of household (responsible for the maintenance of the house) of both sexes from different economic classes, randomly selected from the population living in the city of Piacatu, São Paulo state (SP), in the Southeast region of Brazil. The Criterion of Economic Classification Brazil (CCEB) proposed by the Brazilian Association of Research Companies (ABEP) (6) was used for stratification. Sample size was calculated using the probability proportional to size method, where the representation of each stratum corresponded to at least $22.7 \%$. All subjects signed an informed consent form.

The procedures used to collect the data were as follows: initially, the Fonseca's Questionnaire (7) was applied to assess the level of TMD. The Fonseca's Questionnaire consists of a 10-question form that covers medical history and physical examination. For each question, the possible answers are "yes", "sometimes" or "no", which are assigned the values "10", "5" and "0", respectively. For the global analysis of the questionnaire, all answers were summed. The subjects were classified as "without dysfunction", "with light dysfunction," with moderate dysfunction" and "with severe dysfunction" (ranges from 0-15, 20-40, 45-65 and 70-100, respectively). For those subjects with some degree of TMD the following questionnaires were further applied:

a) Pittsburgh Sleep Quality Index (PSQI) to verify the quality of sleep and sleep disorders over the interval of one month. This survey contains 19 questions of selfevaluation with seven scoring factors: quality, latency, duration, habitual efficiency, disturbances, use of medication to sleep and daily disorders. Five questions are answered by the participant's roommate (if any). Scores include only the self-evaluation questions, which are combined with seven "component" scores, each ranging from 0 to 3 . The score " 0 " indicates no difficulty, while the score " 3 " indicates great difficulty. These seven-component scores are summed in order to obtain a "global" score ranging from 0 to 21 points, where " 0 " indicates no difficulty and " 21 " indicates major difficulties in all areas. A global PSQI score higher than 5 shows great sensitivity $(89.6 \%)$ and specificity $(86.5 \%)$ in diagnostic value in distinguishing between people with and without sleep disorders (8).

b) Social Readjustment Rating Scale (SRRS) to verify the degree of stress on each individual. This survey contains a series of 43 life events, which include positive, negative, frequent and rare events in the past year. In the original scale, the subject is requested to report the events within a certain period (the past month). Weights are assigned to predetermined events as reported, which are summed to obtain the total score. For the overall score, the average values assigned to each life event are summed. If the event happened more than once in the last 12 months, the value is multiplied by the number of occurrences. The score obtained determines the chance that the individual will present any disturbance in their health over the next 2 years, as given by the range within which the individual falls $(30 \%$ - less than or equal to 150 points; $50 \%$ - between 150 and 300 points; $80 \%$ above 300 points). Therefore, the greater the number of life events reported (score), the higher the degree of stress (5).

The data were tabulated using the software Epi Info 2000, version 3.2 and statistically analyzed using the chi-square test at the significance level of $5 \%$. 


\section{Results}

A statistically significant relationship was found when comparing sleep quality and the occurrence of TMD in the sample of 354 individuals (chi-square $=40.32, P=0$ ) (Table 1). A significant association was found between the degree of stress and the occurrence of TMD (chi-square = 17.35, $P<0.01$ ) (Table 2).

Table 1. Comparison between the degree of sleep disorder (Pittsburgh Sleep Quality Index - PSQI) of the respondents and the occurrence of temporomandibular joint dysfunction.

\begin{tabular}{cccc}
\hline PSQI & With dysfunction & Without dysfunction & Total \\
\hline 0 & 1 & 7 & 8 \\
1 & 6 & 31 & 37 \\
2 & 14 & 28 & 42 \\
3 & 21 & 24 & 45 \\
4 & 24 & 31 & 55 \\
5 & 18 & 17 & 35 \\
$6^{*}$ & 24 & 10 & 34 \\
$7^{*}$ & 15 & 5 & 20 \\
$8^{*}$ & 13 & 9 & 22 \\
$9^{*}$ & 10 & 3 & 13 \\
$10^{*}$ & 8 & 4 & 12 \\
$11^{*}$ & 6 & 2 & 8 \\
$12^{*}$ & 7 & 1 & 8 \\
$13^{*}$ & 5 & 2 & 7 \\
$14^{*}$ & 4 & 0 & 4 \\
$17^{*}$ & 2 & 0 & 2 \\
$18^{*}$ & 1 & 0 & 1 \\
$19^{*}$ & 1 & 0 & 1 \\
TOTAL & 180 & 174 & 354 \\
\hline
\end{tabular}

* Chi-square: $P=0$

Table 2. Comparison between the stress level of the respondents and the occurrence of TMD.

\begin{tabular}{lccc}
\hline $\begin{array}{c}\text { Stress degree according } \\
\text { to numbers of life events }\end{array}$ & $\begin{array}{c}\text { With } \\
\text { dysfunction }\end{array}$ & $\begin{array}{c}\text { Without } \\
\text { dysfunction }\end{array}$ & Total \\
\hline 150 or less & 73 & 109 & 182 \\
Between 150 and 300 & 68 & 40 & 108 \\
Above 300 & 39 & 25 & 64 \\
TOTAL & 180 & 174 & 354 \\
\hline
\end{tabular}

* Chi-square: $P<0.01$

Using the Fonseca's Questionnaire, half of the sample $(n=180,50.8 \%)$ had some degree of TMD, and $63(17.8 \%)$ required some kind of treatment (moderate or severe) (Table 3). Regarding socio-demographic characteristics, $102(56.7 \%)$ subjects were male and $157(87.2 \%)$ belonged to lower socioeconomic classes (C, D or E), according to the Criterion of Economic Classification Brazil (CCEB) (6).

The majority of respondents with TMD $(107$, or $59.5 \%)$ had higher degrees of stress (reported more life events) (Table 4). A global PSQI score $>5$ was found in 96 (53.3\%) of the respondents (Table 5).
Table 3. Number and percentage of respondents with respect to the degree of TMD.

\begin{tabular}{lcc}
\hline \multicolumn{1}{c}{ Dysfunction degree } & $\mathrm{N}$ & $\%$ \\
\hline Without dysfunction & 174 & 49.2 \\
Light dysfunction & 117 & 33.0 \\
Moderate dysfunction & 44 & 12.4 \\
Severe dysfunction & 19 & 5.4 \\
TOTAL & 354 & 100.0 \\
\hline
\end{tabular}

Table 4. Number and percentage of respondents with respect to the degree of stress.

\begin{tabular}{|c|c|c|}
\hline $\begin{array}{c}\text { Stress degree according to numbers of } \\
\text { life events }\end{array}$ & $N$ & $\%$ \\
\hline 150 or less & 73 & 40.5 \\
\hline Between 150 and 300 & 68 & 37.8 \\
\hline Above 300 & 39 & 21.7 \\
\hline TOTAL & 180 & 100.0 \\
\hline
\end{tabular}

Table 5. Number and percentage of respondents with respect to the degree of sleep disorder (Pittsburgh Sleep Quality Index - PSQI).

\begin{tabular}{|c|c|c|c|c|c|}
\hline PSQI & $\mathrm{N}$ & $\%$ & PSQI & $\mathrm{N}$ & $\%$ \\
\hline 0 & 1 & 0.6 & 9* & 10 & 5.6 \\
\hline 1 & 6 & 3.3 & $10^{*}$ & 8 & 4.4 \\
\hline 2 & 14 & 7.8 & $11^{*}$ & 6 & 3.3 \\
\hline 3 & 21 & 11.7 & $12^{*}$ & 7 & 3.9 \\
\hline 4 & 24 & 13.3 & $13^{*}$ & 5 & 2.8 \\
\hline 5 & 18 & 10.0 & $14^{*}$ & 4 & 2.2 \\
\hline $6^{*}$ & 24 & 13.3 & $17^{*}$ & 2 & 1.1 \\
\hline $7^{*}$ & 15 & 8.3 & $18^{*}$ & 1 & 0.6 \\
\hline \multirow[t]{2}{*}{$8^{*}$} & 13 & 7.2 & $19^{*}$ & 1 & 0.6 \\
\hline & & & TOTAL & 180 & 100.0 \\
\hline
\end{tabular}

A significant association between the degree of stress and the occurrence of sleep disorders was detected in subjects with TMD (chi-square $=11.21, P<0.01)$, but not in subjects without TMD $(P=0.83)$ (Table 6).

Table 6. Comparison between the stress level of respondents and the occurrence of sleep disorders in patients with and without TMD.

\begin{tabular}{llccc}
\hline TMD & $\begin{array}{c}\text { Stress degree } \\
\text { according to } \\
\text { numbers of } \\
\text { life events }\end{array}$ & $\begin{array}{c}\text { With sleep } \\
\text { disorder }\end{array}$ & $\begin{array}{c}\text { Without } \\
\text { sleep } \\
\text { disorder }\end{array}$ & Total \\
\hline With TMD & 150 or less & 29 & 44 & 73 \\
$(P<0.01)$ & Between 150-300 & 39 & 29 & 68 \\
& Above 300 & 28 & 11 & 39 \\
& TOTAL & 96 & 84 & 180 \\
Without TMD & 150 or less & 21 & 88 & 109 \\
$(P=0.826)$ & Between 150 - 300 & 9 & 31 & 40 \\
& Above 300 & 6 & 19 & 25 \\
& TOTAL & 36 & 138 & 174 \\
\hline
\end{tabular}




\section{Discussion}

The present study showed that, according to the Fonseca's Questionnaire, $50.8 \%$ of subjects had some degree of TMD. In contemporary society, TMD, sleep disorders and physical and psychological stress are all frequent complaints $(1,9,10)$. Although many patients did not complain of any symptoms related to TMD, some studies suggest that $40 \%$ to $60 \%$ of subjects in the general population have some type of TMD (1). More recent studies show a prevalence ranging from $2 \%$ to $5 \%(11)$.

In this sample of adult subjects, quality of sleep and stress levels were associated with TMD, and a significant relationship was found between the three stress scores and the presence or absence of sleep disorders given that an overall PSQI score $>5$ indicates a subject with sleep problems. Estimates of the prevalence of sleep disorders vary due to differences in the methodologies used and the different analyses of the disorder, which results showing up to $40 \%$ of the population affected by snoring and sleepiness and $50 \%$ by insomnia (9). Stressors can cause stress that is either beneficial or harmful, known as eustress and distress, respectively. For the adult population, the prevalence and distribution of psychological distress varies, ranging from $14 \%$ to $33.2 \%$ depending on the instrument used (10). The prevalence of these three diseases is consistent with those observed in the present study.

TMDs have multifactorial etiologies with observed associations with sleep disorders and stress (12-16). Previous studies have reported a strong association between sleep disorders and certain types of stress (14,1721). Polysomnographic findings have shown that stress is associated with a decreased total sleep time, fragmentation and possibly reductions in stages 3 and 4 sleep. Sleep disorders cause an increase in levels of traditional markers of stress, such as cortisol, and exacerbate the effects of stress (19).

One taxonomically specific category of stress is posttraumatic stress disorder (PTSD). PTSD is characterized by a psychological disturbance caused by a sharply painful event, such as an accident or serious aggression, such as trauma due to violence. The traumatic event is persistently relived by the individual, causing intense suffering and a poor quality of life. In patients suffering from post-traumatic stress, the onset of sleep disorders is common (20) and the main complaints are anxious awakenings, nightmares and insomnia (22).

Insomnia presents as the most prevalent sleep disorder seen in psychiatric disorders. It is defined as difficulty in initiating or maintaining sleep, which leads to non-restorative sleep insufficient for maintaining a good quality of alertness and wellness during the day (17). Terminal insomnia or early awakening is related to depression (22). Less common than insomnia is excessive daytime sleepiness or hypersomnia, which is characterized by an increased propensity to sleep and a subjective compulsion to sleep or take involuntary naps, or to have "sleep attacks". Healthy individuals may have hypersomnia temporarily for a few nights or days after a continuous period of sleep deprivation or strenuous physical effort. However, if the hypersomnia lasts more than a few days, it can be a symptom of a psychological disorder such as anxiety, severe depression, or stress $(21,23)$.

Emotional stress can cause muscle hyperactivity presenting as bruxism or teeth clenching. Sleep bruxism is a parasomnia characterized by periodical, involuntary gnashing of the teeth accompanied by sounds similar to the friction of "granite against granite", a symptom usually reported by family members that arises from the rhythmic contraction of the masseter muscles during sleep (24). Ahlberg et al. (18) have reported on bruxism and psychosocial symptoms (stress, sleep disorders and pain) of temporomandibular disorders and concluded that stress, sleep disorders, pain and signs related to TMD are also associated with bruxism. Yatani et al. (25) have attempted to relate quality of sleep, pain and psychological stress in patients with TMD. They used PSQI to check the quality of sleep, with an average cut (total score) of 10. The results of the study supported the relationship between frequent severe pain, psychological stress and sleep disturbance in patients with TMD. The present study found an association between sleep disorders and stress, although no differentiation was made between the different types.

Pain is the most frequent symptom of temporomandibular joint dysfunction and is likely to lead to the occurrence of sleep disorders and stress. Stress, in turn, seems to cause a vicious cycle in terms of sleep, where the person is stressed due to difficulty in sleeping, and the resulting lack of sleep leaves the patient even more nervous.

The present study has some limitations, as it showed the absence or presence and degree of TMD; however, the type of TMD was not diagnosed. In addition, no imaging or clinical exams were used to confirm the diagnosis or to observe systemic problems in the sample. The TMD index used has not been validated against the RDC/TMD questionnaire, nor has the sleep questionnaire been validated against polysomnography. However, the instruments used to detect TMD and sleep problems may be considered adequate for screening in the population because of their simplicity of use and research value.

\section{Conclusions}

Within the limitations of this study, quality of sleep and stress levels were associated with TMD in this sample. 


\section{References}

1. Okeson JP. Etiologia e identificação dos distúrbios funcionais no sistema mastigatório. In: Tratamento das desordens temporomandibulares e oclusão. 4. ed. São Paulo: Artes Médicas; 2000. p. 117-272.

2. Almeida GPL, Lopes HF. Síndrome metabólica e distúrbios do sono. Rev Soc Cardiol Estado de São Paulo 2004; 14:630-5.

3. Duailibi K, Santos MESB. Estresse e sono. In: Reimão R. Avanços em medicina do sono. São Paulo: Associação Paulista de Medicina; Zeppelini Editorial; 2001. p.183-8.

4. Portnoi AG. Estresse e distúrbios craniomandibulares. In: Barros JJ, Rode SM, Coord. Tratamento das disfunções craniomandibulares: ATM. São Paulo: Santos; 1995. p.165-8.

5. Holmes $\mathrm{TH}$, Rahe RH. The social readjusment rating scale. J Psychosom Res 1967;1 1:213-8.

6. Associação Brasileira de Empresas de Pesquisa. Critério de Classificação Econômica Brasil. [cited 2005 Mar 10]. Available from: http://www.abep.org/codigosguias/ABEP_CCEB_2003.pdf

7. Fonseca DM, Bonfante G, Valle AL, Freitas SFT. Diagnóstico pela anamnese da disfunção craniomandibular. RGO 1994;42:23-8.

8. Buysse DJ, Reynolds CF, Monk TH, Berman SR, Kupfer DJ. The Pittsburg sleep quality index: a new instrument for psychiatric practice and research. Psychiatry Res 1989;28:193-213.

9. Rocha FL, Lima e Costa MFF. Epidemiologia e impacto dos distúrbios do sono. J Bras Psiquiatr 2000;49:167-80.

10. Sparrenberger F, Santos I, Lima RC. Epidemiologia do distress psicológico: estudo transversal de base populacional. Rev Saúde Pública 2003;37:434-9.

11. Grossi ML. Disfunção de articulação temporomandibular. In: Antunes JLF, Peres MA, editors. Epidemiologia da saúde bucal. Rio de Janeiro: Guanabara Koogan; 2006. p.152-7.

12. Grossi ML, Goldberg MB, Locker D, Tenenbaum HC. Reduced neuropsychologic measures as predictors of treatment outcome in patients with temporomandibular disorders. J Orofac Pain 2001;15:329-39.

13. Selaimen C, Brilhante D, Grossi ML. Evaluation of the Sleep Assessment Questionnaire (SAQ) in patients with temporomandibular disorders. Rev Odonto Ciênc 2004;19:224-32.
14. Selaimen CMP, Jeronymo JC, Brilhante DP, Grossi ML. Sleep and depression as risk indicators for temporomandibular disorders in a cross-cultural perspective: a case-control study. Int J Prosthodont 2006; 19:154-61.

15. Martins RJ, Garcia AR, Garbin CAS, Garbin AJl. Clase social y trastornos del sueño: relación con los desórdenes temporomandibulares. Rev Asoc Odontol Argent 2007;95:221-8.

16. Martins RJ, Garcia AR, Garbin CAS, Sundefeld MLMM. Associação entre classe econômica e estresse na ocorrência da disfunção temporomandibular. Rev Bras Epidemiol 2007;10: 215-22.

17. Souza JC, Reimão R. Epidemiologia da insônia. Psicol estud 2004;9:3-7.

18. Ahlberg K, Ahlberg J, Könönen $M$, Alakuijala A, Partinen $M$, Savolainen A. Perceived orofacial pain and its associations with reported bruxism and insomnia symptoms in media personnel with or without irregular shift work. Acta Odontol Scand 2005;63:213-7.

19. Akerstedt T. Psychosocial stress and impaired sleep. Scan J Work Environ Health 2006;32:493-501.

20. Lamarche LJ, Koninck J. Sleep disturbance in adults with posttraumatic stress disorder: a review. J Clin Psychiatry 2007;68: 1257-70.

21. Souza JC, Souza N, Arashiro ESH, Schaedler R. Sonolência diurna excessiva em pré-vestibulandos. J Bras Psiquiatr 2007;56: 184-7.

22. Lucchesi LM, Pradella-Hallinan M, Lucchesi M, Moraes WAS. O sono em transtornos psiquiátricos. Rev Bras Psiquiatr 2005; 27:27-32.

23. Bittencourt LRA, Silva RS, Santos RF, Pires MLN, Mello MT. Sonolência excessiva. Rev Bras Psiquiatr 2005;27:16-21.

24. Alóe F, Gonçalves LR, Azevedo A, Barbosa RC. Bruxismo durante o sono. Rev Neurocienc 2003;1 1:4-17.

25. Yatani H, Studts J, Cordova M, Carlson CR, Okeson JP. Comparison of sleep quality and clinical and psychologic characteristics in patients with temporomandibular disorders. J Orofac Pain $2002 ; 16: 221-8$. 